NIST

PUBLICATIONS

\title{
THE EVALUATION OF THERMAL BRIDGES USING A MOBILE TEST FACILITY
}

\section{Jin B. Fang Richard A. Grot}

U.S. DEPARTMENT OF COMMERCE Natlonal Instltute of Standards and Technology

Center for Bullding Technology Bullding Envlronment Divislon Galthersburg, MD 20899

Prepared for Offlce of BulldIng Energy Research and Development U.S. Department of Energy WashIngton, DC 20585

U.S. DEPARTMENT OF COMMERCE Robert A. Mosbacher, Secretary

Lee Mercer, Deputy Under Secretary for Tochnology

NATIONAL INSTITUTE OF STANDARDS AND TECHNOLOGY

John W. Lyons, Director 
NATIONAL INSTITUTE OF STANDARDS \&

TECHNOLOGY

Research Information Center

Gaithersburg, MD 20899

\section{DATE DUE}

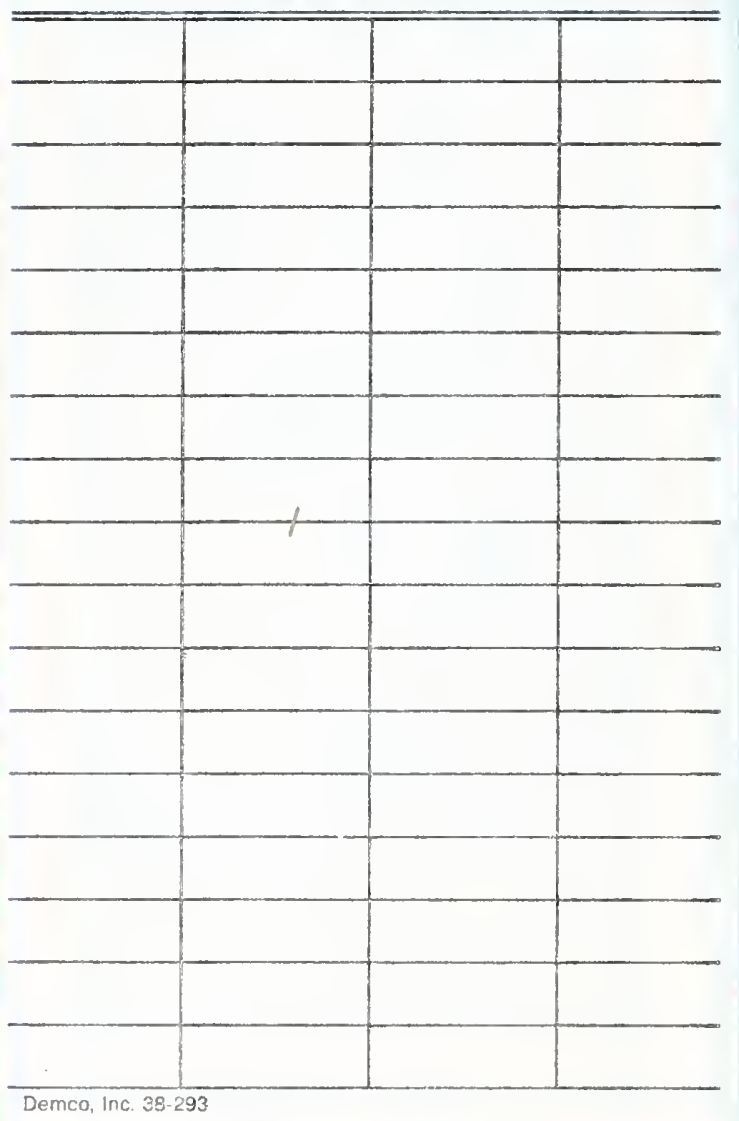




\section{THE EVALUATION OF THERMAL BRIDGES USING A MOBILE TEST FACILITY}

\section{Jin B. Fang \\ Richard A. Grot}

U.S. DEPARTMENT OF COMMERCE Natlonal Institute of Standards and Technology Center for Bullding Technology Bullding Envlronment Divislon Galthersburg, MD 20899

Prepared for:

Offlce of Bullding Energy Research and Development U.S. Department of Energy Washington, DC 20585

March 1990

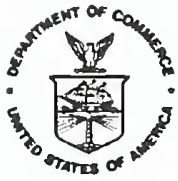

U.S. DEPARTMENT OF COMMERCE Robert A. Mosbacher, Secretary Lee Mercer, Deputy Under Secretary for Tochnology

NATIONAL INSTITUTE OF STANDARDS AND TECHNOLOGY

John W. Lyons, Director 



\section{ABSTRACT}

The construction details of a mobile test facility with removable walls and roof used for installation and performance evaluation of the test specimens are described. Descriptions of the overall performance of a newly developed portable calorimeter employed for quantification of the heat flow through exterior walls of a building corner are given. Laboratory tests were conducted using an in-situ thermal resistance measurement technique to evaluate the performance of thermal bridges occuring in a metal-frame, insulated wall construction. The local heat flow rates and thermal resistances under steady-state conditions were measured by means of portable calorimeters, heat flux transducers and thermistors at various locations of the test structure. The measured wall thermal resistance values were compared with the predicted values obtained by the zone and the series/parallel resistance methods. The calorimeter measurement generally gave lower thermal resistance values than the heat flux transducers due to enhanced heat conduction through highly conductive fasteners and framing members.

Key Words: Building, exterior envelope, heat flux, in-situ measurements, portable calorimeter, temperature, thermal bridge, thermal resistance, wall. 

1. Introduction. . . . . . . . . . . . . . . . . . . . .

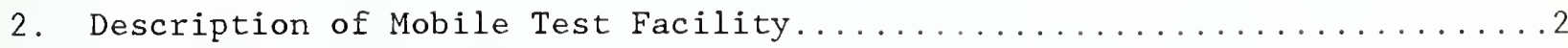

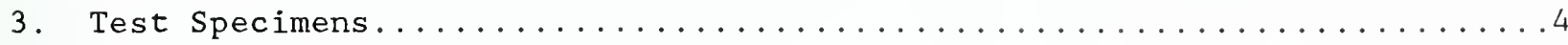

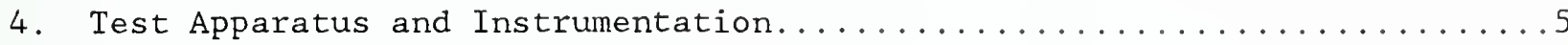

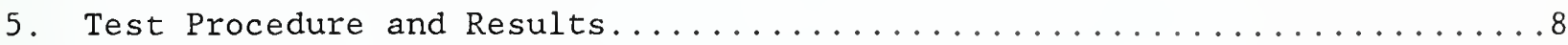

6. Conclusions and Recommendations........................ 12

7. Acknowledgement................................... 14

8. References...........................................

\section{List of Tables}

Table 1. Wall Thermal Resistance Measured with Portable Calorimeters and Heat Flux Transducers for Metal Framed Walls...............

Table 2. Comparison of Wall Thermal Resistance Measured with Portable Calorimeters and Heat Flux Transducers to Corresponding Predicted Values for Metal Framed Wall Construction...........16

\section{List of Figures}

Figure 1. Mobile Test Facility with Removable Walls and Roof...........17

Figure 2. Chassis of Mobile Test Facility..................... 17

Figure 3. Installation of Wall Framings......................

Figure 4 . Installed Wall Sections...................... 17

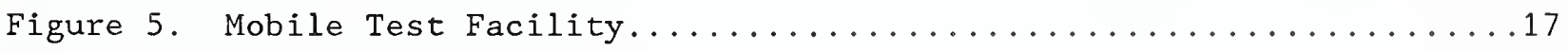

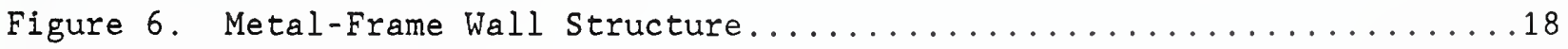

Figure 7. Wood-Frame Wall Structure........................ 19

Figure 8a. Masonry Wall and Concrete Floor Constructions...............20

Figure 8b. Front View of Masonry Wall and Concrete Floor Constructions..... 20

Figure 8c. Details of Reinforced Concrete Floor in the Masonry Wall and Concrete Floor Constructions....................... 20

Figure 9. Construction Details of Portable Calorimeter for Flat Surface...20 
Figure 10a. Construction Details of Portable Calorimeter for Surfaces of a

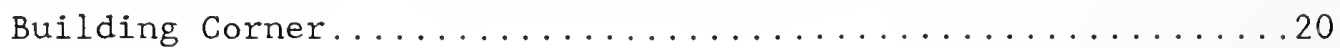

Figure $10 \mathrm{~b}$. Front View of the Corner Calorimeter .................20

Figure 11. Sensor Locations on the Metal-Frame Wall Construction........20 


\section{Introduction}

The exterior envelope of a building often contains thermal bridges that allow localized excessive heat flows. Thermal bridges increase the energy consumption for heating and cooling of the building. For example, heat conducted through thermal bridges in concrete deck floors which penetrate insulated exterior walls of office buildings represents a considerable portion of total heat loss through the exterior envelopes [1]. With the increase in insulation levels in the building envelopes, the heat loss through thermal bridges becomes more noticeable.

A thermal bridge occuring in a building envelope generally has a smaller cross sectional area and is composed of materials with greater thermal conductivity than adjacent materials within the exterior envelope. During the heating season, the thermal bridge can produce localized regions of lower temperature on the inner surface and higher temperature on the outer surface of the building envelope in comparison with surrounding wall surfaces. In addition to the increased rate of heat loss from the building, this lowtemperature area formed at a thermal bridge also can result in surface condensation of indoor moisture. Condensate can lead to growth of molds and deterioration of building materials.

The overall heat transmission coefficients for a variety of roof and wall constructions of metal buildings were measured recently in a guarded hot box by Snyder [2]. Brown [3] performed thermal transmission tests on different configurations of sheet steel walls using a guarded hot box test apparatus (ASTM C236) and found that the heat conducted through steel 
Z-girts can constitute up to 35 percent of total heat flow through the test wall. Most computer codes used for calculating the heating and cooling loads of a building do not account for the effect of thermal bridges present in the constructions involved. To obtain a realistic assessment of the performance of building components, there is a need to acquire basic data for assessing the impact of thermal bridges and to provide information on experimental verification of theoretical models.

This report describes a mobile test facility and portable calorimeters developed specifically to evaluate the performance of thermal bridges in building envelopes in the field. The results of thermal resistance measurements of a metal panel faced wall structure under laboratory controlled conditions also are presented in this report.

\section{Description of Mobile Test Facility}

The mobile test facility was a one-room mobile home. Figure 1 shows a schematic of the mobile test facility constructed to evaluate the effects of thermal bridges and anomalies on the heat loss in exterior envelopes. The test facility had removable walls and roof to be used for installation of test specimens. A gooseneck trailer was built to serve as the base frame for erecting the mobile home (Figure 2). The test facility had external dimensions of 20 feet 1 inch $(6.12 \mathrm{~m})$ long by 8 feet 3 inches $(2.51 \mathrm{~m})$ wide with an 8 feet 10 inch $(2.69 \mathrm{~m})$ height. The dimension excluded a small, 4 feet $(1.22 \mathrm{~m})$ by 8 feet 3 inches $(2.51 \mathrm{~m})$ by 5 feet 2 inches $(1.57 \mathrm{~m}$ ) high compartment built on the hitch, making a total of 24 feet 1 inch (7.34 $\mathrm{m}$ ) in actual length. 
The major features of the trailer used include the following: (1) 10 tons load capacity, (2) 20 feet $(6.10 \mathrm{~m})$ long by 8 feet $(2.44 \mathrm{~m})$ wide, 3/16-inch $(4.8 \mathrm{~mm})$ steel plate deck measuring 2 feet $10(0.86 \mathrm{~m})$ inches above the ground level, (3) 8 feet $(2.44 \mathrm{~m})$ gooseneck length, (4) W10x15 main frame beams at 69 inches $(1.75 \mathrm{~m})$ web-to-web spacing, (5) $3 \times 3 \times 1 / 4$ inch (76 $\mathrm{x}$ $76 \times 6.4 \mathrm{~mm}$ ) wall square steel tubing cross members spaced at 24 inches $(0.61 \mathrm{~m})$ on centers from deck ends, (6) six each $9.00 \times 14.5,12$ ply tires, (7) three 7000 pounds capacity axels with $2 \times 12$-inch electric brakes on all wheels and leaf spring suspension, (8) an adjustable height/removable 2-5/16-inch (59 mm) ball coupler, (9) all welded construction, (10) two 10000-pounds capacity tongue jacks mounted on front of trailer deck, and (11) DOT lighting with breakaway switch.

Floor construction included 2 x 4-inch (51 x $102 \mathrm{~mm}$ ) floor joists running the entire chassis length and secured to the steel deck of the trailer. Floor cavities were insulated with rigid, 1.5 -inch (38 $\mathrm{mm}$ ) polystyrene foam board, and 1/2-inch (13 mm) plywood decking installed throughout the mobile home.

Exterior wall sections were framed with $2 \times 4$-inch (51 x $102 \mathrm{~mm}$ ) wood studs placed along the periphery of the floor and spaced 16 -inch $(0.41 \mathrm{~m})$ on centers (Figure 3 ). Wall cavities were blanketed with $\mathrm{R}-11,3.5$-inch ( $89 \mathrm{~mm}$ ) glass fiber insulation and covered with a layer of 1.5 -inch (38 mm) polystyrene foam board as an additional insulation. Plywood sheathing $(1 / 2-$ inch) (13 mm) covered the outside of the exterior walls (Figure 4). The outside walls were finished with vinyl siding (Figure 5). The interior 
of walls was covered with $1 / 4$-inch $(6.4 \mathrm{~mm})$ plywood paneling.

The roof section was constructed from $2 \times 6$-inch (51 x $152 \mathrm{~mm}$ ) wood framing members spaced 16 -inch $(0.41 \mathrm{~m})$ on centers. The cavities between ceiling framings were filled with R-19, 6-inch (152 mm) thick glass fiber insulation and covered with 1.5 inch $(38 \mathrm{~mm}$ ) polystyrene foam board laid above the interior ceiling for additional insulation. The roof construction had a 1/2-inch (13 mm) plywood ceiling over the side walls, truss type rafters at 16 -inch $(0.41 \mathrm{~m})$ on centers, and a galvanized sheet metal roof.

Three electric heaters each having three output rates of 600,900 and 1500 $W$, respectively, were used to heat the inside air of the mobile test facility. Forced circulation of indoor air was provided by a portable electric fan. The test facility had the capability to accomodate test specimens of various sizes and configurations including 8 feet wide by 8 feet high $(2.44 \times 2.44 \mathrm{~m})$ wall, 4 feet wide by 8 feet high $(1.22 \times 2.44 \mathrm{~m})$ wall perpendicular to 8 feet wide by 8 feet high $(2.44 \times 2.44 \mathrm{~m})$ wall in corner configuration, and 8 feet wide by 8 feet long $(2.44 \times 2.44 \mathrm{~m})$ roof. After construction of the mobile test facility, it was moved into a large environmental chamber at NIST. Supports were placed at various locations under the trailer chassis to take weight off the tires.

\section{Test Specimens}

Two test specimens were fabricated for evaluation of performance. The first wall was a metal-frame wall; the second was a wood frame wall construction. Metal frame walls are used extensively in low-rise and industrial buildings. 
The metal frame wall studied consists of two metal panels, which are insulated and have steel studs framings at corner configuration. Figure 6 shows construction details of the metal-frame wall structure. The test wall was built by fastening 26 gage corrugated exterior sheet metal panels to $8.25 \times 3.50 \times 0.06$-inch $(210 \times 89 \times 1.5 \mathrm{~mm})$ "C" steel studs and horizontal, $8.25 \times 3.50 \times 0.06$-inch $(210 \times 89 \times 1.5 \mathrm{~mm})$ steel Z-girts located at the mid-height using No. 12 x 1 -inch self-drilling screws spaced $12(0.31 \mathrm{~m})$ inches apart. An R-11, 3.5 inch ( $89 \mathrm{~mm}$ ) glass fiber insulation blanket was installed on the interior of the sheet metal paneling within the framing cavities. The interior side surface of the test wall was covered with $0.5-$ inch (13 mm) gypsum board. The juctions between boards were finished with joint compound and taped. The wall contained approximately 3.75 inch (95 $\mathrm{mm}$ ) thick airspace between the blanket insulation and gypsum wallboard.

The corner detail of the wood-frame walls is given in Figure 7. This wall construction consisted of 0.63 -inch (16 mm) exterior plywood paneling attached to $2 \times 4$-inch $(51 \times 102 \mathrm{~mm})$ wood studs spaced 16 inch $(0.41 \mathrm{~m})$ on center, 0.5 inch $(13 \mathrm{~mm})$ gypsum wallboard fastened to the wood framing members with its joints caulked and taped, and R-11 3.5-inch (89 mm) aluminum foil-faced, batt type, glass-fiber insulation sandwiched between gypsum board and plywood paneling.

A third test wall was planned, but its construction has not yet been completed. Figures 8.a to 8.c show the construction details of a masonry wall with concrete floor construction. Thermal bridges occur at the concrete floor 
and steel decking, which penetrate the insulation layer of the masonry wall.

\section{Test Apparatus and Instrumentation}

To obtain the thermal resistance of a building envelope, measurements of the rate of heat flow and the local air-to-air temperature difference across the envelope are required. The rate of heat flow through a test wall was measured with heat flux transducers and portable calorimeters. The heat flux transducers were 4-in. (102 mm) diameter, thin, circular disk consisting of an embeded thermopile with its hot and cold junctions attached to the internal disk surfaces. The thermopile voltage was directly proportional to the rate of heat transferred through the transducer. Calibration of the heat flux transducters was accomplished prior to the experiments using a standard guarded hot plate apparatus described in reference 4. The accuracy of the transducer calibration was estimated to be within \pm 18 [5].

Two portable calorimeters of different configurations were designed, fabricated, and instrumented to measure the rate of heat flow through flat wall surface and surfaces of a building corner. The detailed construction of the portable calorimeter used for flat surfaces is given in Figure 9. This portable calorimeter can provide wall thermal resistance data within 98 of the results obtained by a calibrated hot box [5]. Figures 10.a and 10.b show the construction details of a portable calorimeter employed to measure heat flow through two wall surfaces of a building corner. The calorimeter walls were fabricated from two layers of 2 in. (50 mm) thick aluminum foil-faced, semi-rigid glass fiber insulation boards, which were 
glued together with foiled side exposed. All the joints between the insulation boards were staggered, filled with small fragments of glass fiber insulation mixed with adhesive, and covered with aluminum foil duct tape. To further strengthen the complete calorimeter box, the exterior sides of the calorimeter were covered by $0.5 \mathrm{in.}(13 \mathrm{~mm})$ thick plywood support frame. A narrow rubber foam strip was installed along the edges of the open faces of the calorimeter box to provide an air-tight seal between the calorimeter and the wall surfaces to be tested. The calorimeter had two metering areas each measuring 26 in. $(0.66 \mathrm{~m})$ wide by 36 in. (0.91m) long in size.

The corner wall calorimeter contained a nominal $180 \mathrm{~W}$ electrical resistance heater consisting of nickel chromium wire having a B \& S gage No. 24 wire diameter. Steel springs and hooks held the wire to ceramic standoff insulators fastened to the plywood frame. A thermopile consisting of 16 thermocouple pairs placed evenly on both the inner and outer surfaces of the calorimeter back walls, was used to monitor the temperature differential across the calorimeter walls. The thermocouples were constructed from B \& $\mathrm{S}$ gage No. 27 copper and constantan wires with a 0.015 -inch $(0.38 \mathrm{~mm})$ diameter and nylon insulation.

Each portable calorimeter had an automatic measurement and control system which consisted of a controller, a watt-hour meter, and a safety thermostat. A voltage controller, using the thermopile output as the feedback variable, was utilized for controlling the operation of the electric heater and maintaining a zero temperature difference across the calorimeter box walls. 
The total electrical energy consumed by the heater was measured with a watt-hour meter equipped with an optoelectronic device consisting of a light-emitting diode and a detector. This device generated an electric pulse from one-half revolution of the disk inside the meter for each period of time with an electrical energy consumption of $0.15 \mathrm{~W} . \mathrm{h}$. These pulses were totalled and registered by an electronic counter. A safety thermostat with a sensing element installed in the calorimeter provided control of calorimeter air temperature within the safety limit by opening an electrical circuit at high temperatures. Since the heat losses through the box walls and the edges that contacted the metered surface were approximately nulled to zero, the electrical energy supplied to the heater was essentially equal to the heat flow through the metered area.

Thermistors were used to measure the temperatures of the ambient air within the environmental chamber, the indoor air in the vicinty of the heat flux transducers, and the air inside the portable calorimeter boxes. Each temperature sensor consisted of a bead-shaped thermistor and an external network with fixed precision resistors. The thermistor under an applied voltage of $1.2 \mathrm{~V}$ direct current (DC) produced an output voltage proportional to the temperature over a temperature range between - 22 and $122^{\circ} \mathrm{F}(-30$ and $50^{\circ} \mathrm{C}$ ). According to the technical data furnished by the manufacturer, the measurement error of the thermistors was within $\pm 0.5^{\circ} \mathrm{F}\left(0.3^{\circ} \mathrm{C}\right)$.

\section{Test Procedure and Results}

A series of tests was conducted in the environmental chamber to determine the thermal performance of the metal frame walls at a building corner using 
the heat flux transducers, portable calorimeters and thermistors. The test wall was held in place through wood frames with its outer wall surfaces sealed against the environmental chamber in which the temperature was maintained at a constant value or changed with time in a controlled manner to simulate outdoor weather conditions. The wood frames used for installing the test specimen were attached to the perimeter of the open-side rear and side walls of the mobile test facility. For the series of tests performed, the cold side air temperature in the environmental chamber was controlled at $47^{\circ} \mathrm{F}\left(8.3^{\circ} \mathrm{C}\right)$ and the hot side air temperature in the mobile home at $73^{\circ} \mathrm{F}\left(22.8^{\circ} \mathrm{C}\right)$.

Nine heat flux transducers were taped on the internal surface of the rear wall and one transducer was attached to the inside surface of the side wall at locations indicated in Figure 11. The open side of the calorimeter boxes were sealed with duct tape against the inner surfaces of the test wall. The ambient air temperatures were measured with two thermistor placed at the same levels as the top and bottom of outer surfaces of the test structure. Each thermistor was installed with its sensing element positioned 4 inchs $(102 \mathrm{~mm})$ from the exposed measurement surface. The output signals from the heat flux transducers, the electric pulses from the watt-hour meters used with the portable calorimeters, and the thermistors were recorded simultaneously by a micro-computer based data acquisition system. This system was capable of recording data from 15 thermistors, 15 heat flux transducers and 10 calorimeters simultaneously. Continuous readings of all transducers were taken at two second intervals. The computer averaged the readings over a 10 minute intervals, and recorded the test data on a floppy disk for 
further data reduction and analysis.

Thermal resistance results for metal framed walls as measured with both the flat and corner wall portable calorimeters and the heat flux transducers are summarized in Table 1. Heat fluxes were measured at mid-height locations where Z-girts existed and also at areas over the cavities between steel framings and girts. All of the measured data obtained from the in-situ methods are mean values of the data collected over a 24-hour period for 5 consecutive days. Error due to transient effect resulting from the large thermal storage of building envelope can generally be minimized by averaging the air temperature and surface heat flux data over a 24-hour period. The thermal resistance, $R$ value, defined as the ratio of the average temperature difference between the interior and exterior air across the building envelope to the average heat flow rate, was calculated from the following relation:

$$
R=\int_{0}^{\tau}(\Delta \mathrm{T}) d t / \int_{0}^{\tau} \mathrm{qdt}
$$

where $\Delta \mathrm{T}$ is the air-to-air temperature difference, $\mathrm{q}$ is the rate of heat flow through the building envelope, and $\tau$ is the length of the measurement period.

Small variations in the exterior and interior air temperatures were recorded throughout the test duration. Correspondingly, the measured thermal resistances obtained by the calorimeters and the heat flux transducers at various locations of the test wall varied very little and were practically constant as shown in Table 1. Also presented in the table are the cumulative 
average of wall thermal resistances, the air temperatures within the portable calorimeters, and the indoor air temperatures in the vicinity of heat flux transducers. The cumulative average value was calculated by dividing the sum of the daily thermal resistance or air temperature value by the number of days elapsed.

A comparison of the measured and the predicted thermal resistances for the metal-frame wall is presented in Table 2. The average wall thermal resistance values for the heat flux transducers as given in the table were the average values of the resistance data obtained from three transducers mounted on the interior surface of the rear wall. The predicted steady-state thermal resistance values, which included the average $\mathrm{R}$ value for the wall construction and the $R$ values for areas at steel girt, at steel stud and between these framing members, were calculated using both the zone and the series/parallel resistance methods [5]. The overall thermal resistance value including the correction for effects of wall framings such as Z-girts and steel studs, was calculated from the following equation:

$\mathrm{R}^{-1}=\mathrm{R}_{\mathrm{f}}^{-1}(8$ framings $/ 100)+\mathrm{R}_{\mathrm{C}}^{-1}(100-8$ framing $) / 100$

where $R$ is the average thermal resistance value, and $R_{f}$ and $R_{c}$ are the thermal resistance values measured at the framing member and at the cavity between framings, respectively.

The published data on thermal properties of the building materials involved and on thermal resistance of vertical airspaces with horizontal heat flow 
[6] were used for calculating the predicted values. The air films at the warm and cold wall were assumed to have thermal resistance values of 0.68 $\mathrm{ft}^{2} \cdot \mathrm{h} .{ }^{\mathrm{o}} \mathrm{F} / \mathrm{Btu}\left(0.12 \mathrm{~m}^{2} \cdot \mathrm{K} / \mathrm{W} \cdot \mathrm{m}^{2} \cdot \mathrm{K} / \mathrm{W}\right)$ and $0.17 \mathrm{ft}^{2} \cdot \mathrm{h} .{ }^{\circ} \mathrm{F} / \mathrm{Btu}(0.03 \mathrm{~m}$ $2 . \mathrm{K} / \mathrm{W}$ ) respectively. These film resistances represent such conditions that the interior side of the building envelope is exposed to still air and the exterior side is subject to a $15 \mathrm{mph}(6.7 \mathrm{~m} / \mathrm{s})$ wind.

As illustrated in Table 2, there is a fairly good agreement between the measured wall thermal resistance values and the predicted results. The thermal resistance determined by the portable calorimeters are generally lower than those measured with heat flux transducers due to the increased heat transmission through highly conductive fasteners and framing members. The measured values for the thermal resistances of the areas over the cavities between metallic framings are significantly smaller than the calculated values probably caused by excessive convection heat losses from the warmer to colder surfaces within the wall assembly. This thermal bypass due to a convection loop mechanism reduced the thermal resistance by approximately $80 \%$ in comparison with the same wall with closed cavities of quiescent air. Significant lower values for measured resistance in comparison with the predicated values may be attributed to multidimensional heat flow conditions prevailing in metallic framing members rather than the one-dimensional heat flow assumed to exist in the thermal resistance calculations. The wall resistance values measured with heat flux transducers deviated from the predicted values by $18 \%$ for the flat wall surface, and by 9 for the walls of a corner. 


\section{Conclusions and Recommendations}

A series of tests was performed for evaluating the performance of thermal bridges occuring in a full-scale-metal frame wall construction using the portable calorimeters, heat flux transducers and thermistors. Both the heat flux transducer and the portable calorimeter were found to be useful tools for in-situ measurement of thermal resistances of composite walls containing structural thermal bridges or highly conductive heat flow paths. The measured wall thermal resistances of the metal-frame building were found to be significantly lower than the predicted values calculated by the zone and the series/parallel resistance methods [6]. The excessive heat loss, which reduced the overall thermal resistance, was caused by structural thermal bridges, and thermal by-pass or convection loop mechanism resulting from buoyancy-driven flows of air in the confined airspaces within the wall construction. The calorimeter measurement generally gave lower thermal resistance values in comparison to the heat flux transducers because of the substantial effect of thermal bridging caused by highly conductive fasteners and framing members. The corner calorimeter was capable of being used to measure the average heat flow rates and thermal resistances of exterior walls of a building corner in the field.

To improve and determine the measurement accuracy, further work is recommended to compare the measured data with the predicted results from the validated computer programs developed based on finite difference or finite element numerical techniques. To obtain test data for assessing the heat loss effects of thermal bridges and verifying the predictions of theoretical models, it is recommended to continue experimental evaluation of the 
performances of the wood-framed wall and the masonry wall with concrete floor construction.

7. Acknowledgement

The work reported here was sponsored by the Office of Building Energy Research and Development, U. S. Department of Energy, through an interagency agreement with the National Institute of Standards and Technology. The authors would like to thank Doug Pruitt of NIST for his assistance in constructing the mobile test facility and in obtaining the test data used in this report.

8. References

1. Grot, R. A., Childs, K. W., Fang, J. B. and Courville, G. E., "The Measurement and Quantification of Thermal Bridges in Four Office Buildings, " ASHRAE Transactions, Vol. 91, Part 1 B, 558-573 (1985).

2. Snyder, M. K., "Heat-Transmission Coefficients for Metal Building Systems," ASHRAE Transactions, Vol. 92, Part 2 B, 577-583 (1986).

3. Brown, W. C., "Heat-Transmission Tests on Sheet Steel Walls", ASHRAE Transactions, Vol 92, Part 2B, 554-5666 (1986).

4. Powell, F.J. and Rennex, B. J., "NBS Line-Heat-Source Guarded Hot Plate for Thick Materials," in 'Thermal Performance of the Exterior Envelopes of Buildings II,' ASHRAE SP 38, 1982.

5. Fang, J. B., Grot, R. A. and Park, H. S., "The Assessment of Accuracy of In-Situ Methods for Measuring Building Envelope Thermal Resistance," Thermal Performance of the Exterior Envelopes of Buildings III, ASHRAE SP 49, pp.675-688, 1986.

6. ASHRAE Handbook of Fundamentals, SI Edition, American Society of Heating, Refrigerating and Air Conditioning Engineers, Atlanta, GA, 
1989, Chapter 22, pp 2-14.

Table 1. Wall Thermal Resistance $\left(\mathrm{ft} \mathrm{t}^{2} \cdot \mathrm{h} .{ }^{\circ} \mathrm{F} / \mathrm{Btu}\right)$ Measured Portable Calorimeters (PC) and Heat Flux Transducers (HFT) for Metal-Frame Walls

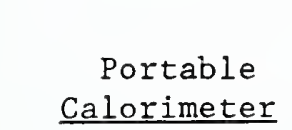

wall

Heat Flux Transducer
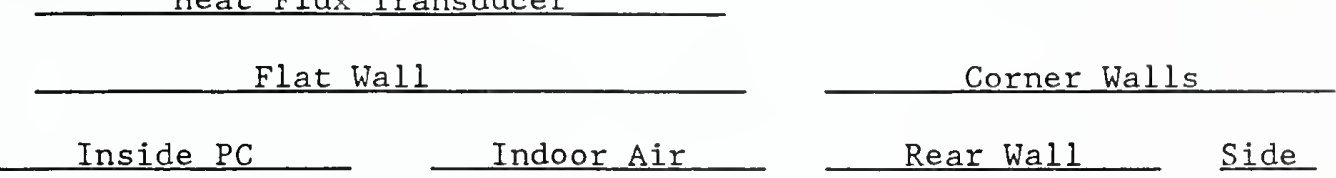

Date Flat $\underline{\text { Corner }}$ Top Mid. Bott. Top Mid. Bott. Top Mid. Bott. Mid.

\begin{tabular}{|c|c|c|c|c|c|c|c|c|c|c|c|c|}
\hline $4 / 13$ & 3.4 & 4.2 & 4.4 & 5.2 & 12 & 8.0 & 4.5 & 6.1 & 4.9 & 7.5 & 8.8 & 6.0 \\
\hline $4 / 14$ & 3.4 & 4.2 & 4.4 & 5.2 & 12 & 7.9 & 4.5 & 6.1 & 4.9 & 7.5 & 8.8 & 6.0 \\
\hline $4 / 15$ & 3.5 & 4.2 & 4.5 & 5.3 & 12 & 7.9 & 4.5 & 6.2 & 4.9 & 7.6 & 8.8 & 6.0 \\
\hline $4 / 16$ & 3.4 & 4.2 & 4.5 & 5.2 & 12 & 7.9 & 4.5 & 6.2 & 4.9 & 7.6 & 8.8 & 6.0 \\
\hline $4 / 17$ & 3.4 & 4.2 & 4.5 & 5.2 & 12 & 7.9 & 4.5 & 6.1 & 4.9 & 7.5 & 8.8 & 6.0 \\
\hline $\begin{array}{l}\text { Average } \\
\text { R-value }\end{array}$ & 3.4 & 4.2 & 4.5 & 5.2 & 12 & 7.9 & 4.5 & 6.1 & 4.9 & 7.5 & 8.8 & 6.0 \\
\hline $\begin{array}{l}\text { Average } \\
\text { Temp. }\end{array}$ & $\begin{array}{l}71 \\
\text { F) }\end{array}$ & 71 & 73 & 73 & 69 & 74 & 73 & 73 & 73 & 71 & 69 & 71 \\
\hline
\end{tabular}

Note: Average ambientair temperature was $48^{\circ} \mathrm{F}$ 
Table 2. Comparison of Wall Thermal Resistances (ft ${ }^{2} . h^{\circ} \mathrm{F} / \mathrm{Btu}$ ) Measured with Portable Calorimeters (PC) and Heat Flux Transducers (HFT)

to Corresponding Predicted Values for Metal Frame Wall Construction Measured Values

\begin{tabular}{|c|c|c|c|c|c|c|c|c|}
\hline \multirow[b]{2}{*}{ Component } & \multirow[b]{2}{*}{$\mathrm{PC}$} & \multicolumn{3}{|c|}{ HFT } & \multicolumn{3}{|c|}{ Predicted Values } & \\
\hline & & $\begin{array}{c}\text { At } \\
\text { Girt } \\
\end{array}$ & $\begin{array}{l}\text { Between } \\
\text { Framings }\end{array}$ & $\underline{\text { Avg. }}$ & $\begin{array}{c}\text { At } \\
\text { Girt }\end{array}$ & $\begin{array}{l}\text { At } \\
\text { Stud }\end{array}$ & $\begin{array}{l}\text { Between } \\
\text { Framings }\end{array}$ & Avg \\
\hline Flat Wall & 3.4 & 4.5 & 7.0 & 6.2 & 3.2 & & 13 & 8.1 \\
\hline Corner & 4.2 & $6.8 x$ & $6.9 *$ & $6.8 x$ & 3.3 & 2.4 & 13 & 6.2 \\
\hline
\end{tabular}

Note:

*The measured values were obtained with the heat flux transducers installed inside the portable calorimeters.

$1 \mathrm{ft} \mathrm{t}^{2} \cdot \mathrm{h} \cdot \mathrm{oF} / \mathrm{Btu}=0.176 \mathrm{~m}^{2} \cdot \mathrm{K} / \mathrm{w}$. 


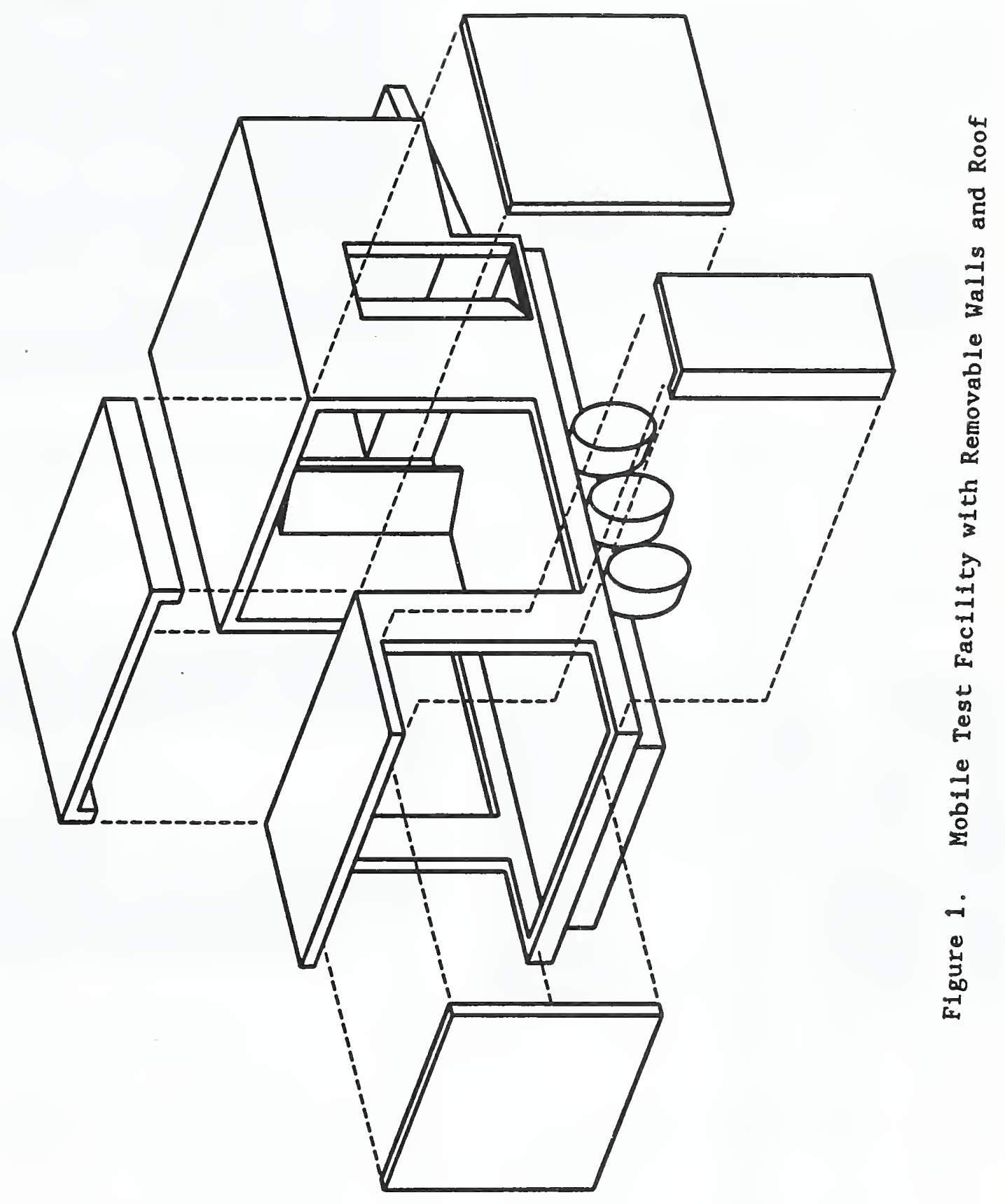




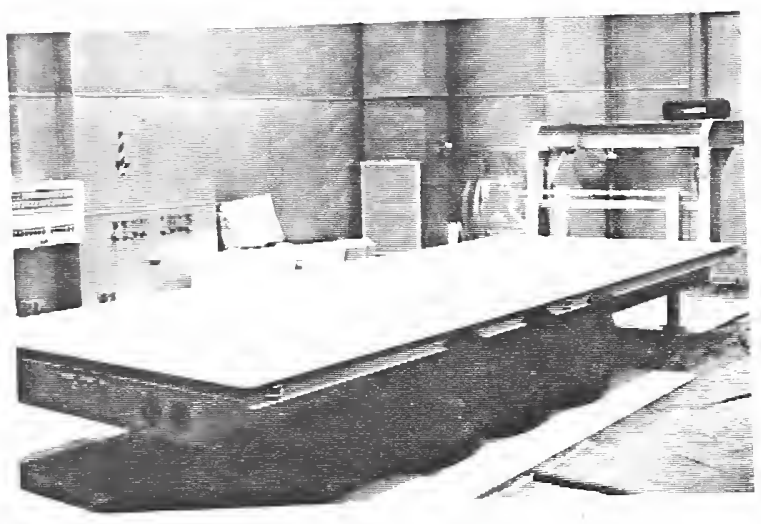

Figure 2. Chassis of Mobile Test Facility

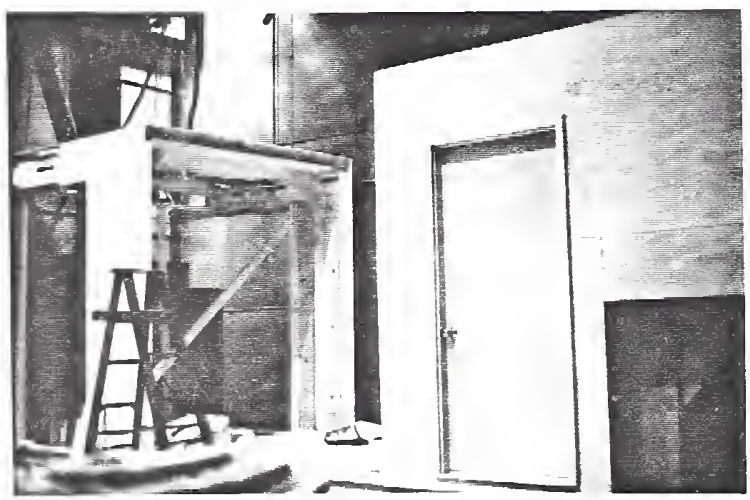

Figure 4. Installed Wall Sections

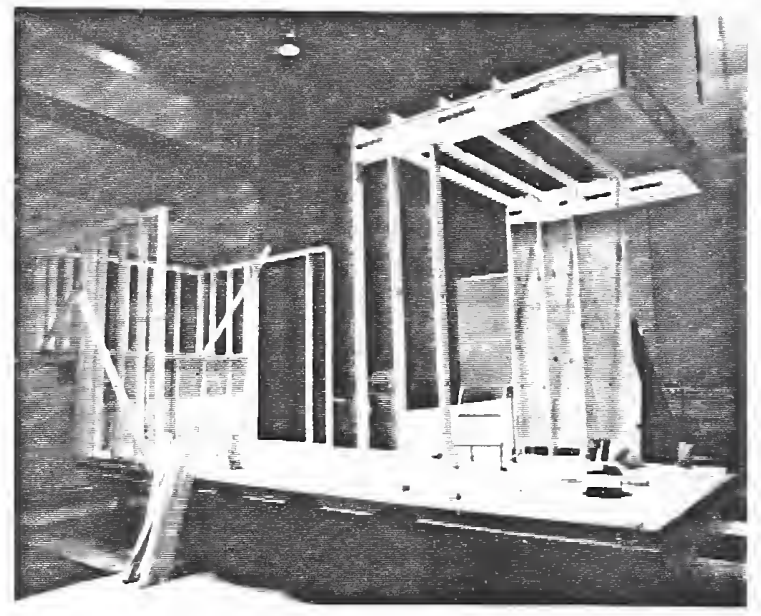

Figure 3. Installation of Wall Framings

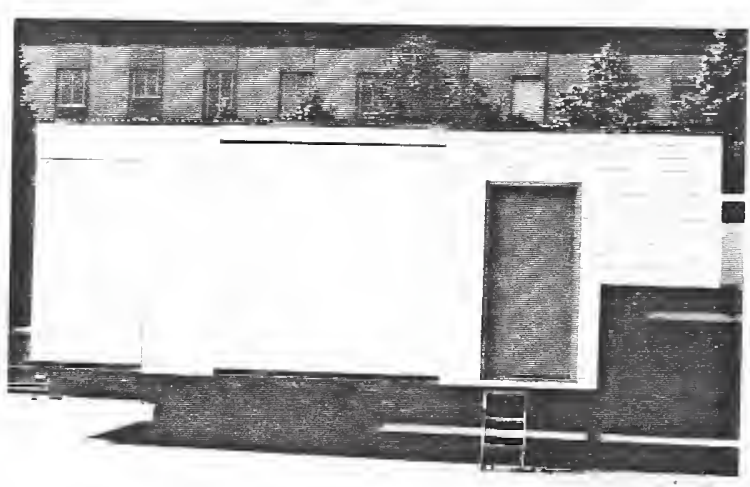

Figure 5. Mobile Test Facility 


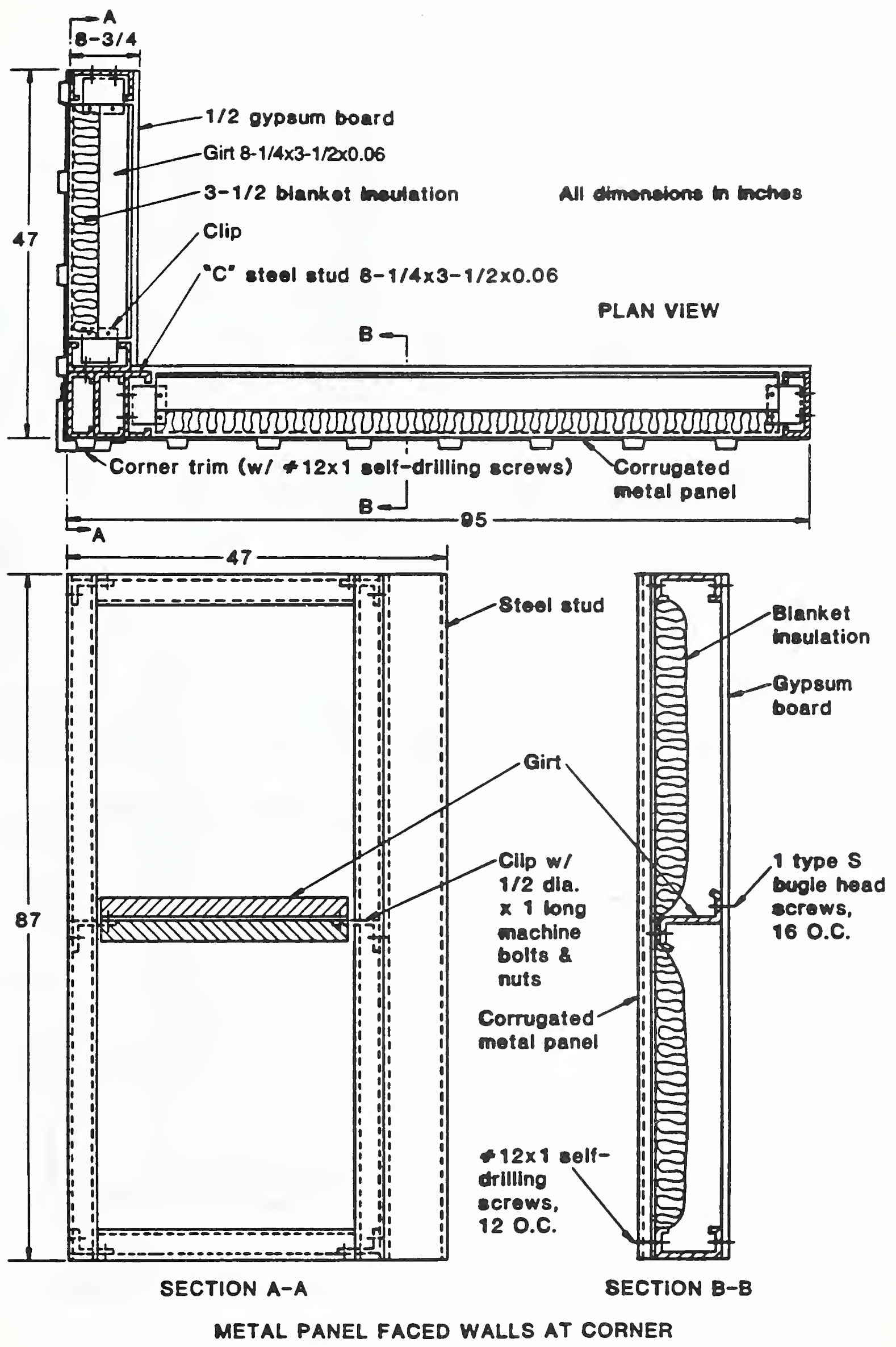

Figure 6. Metal-Frame Wall Structure 

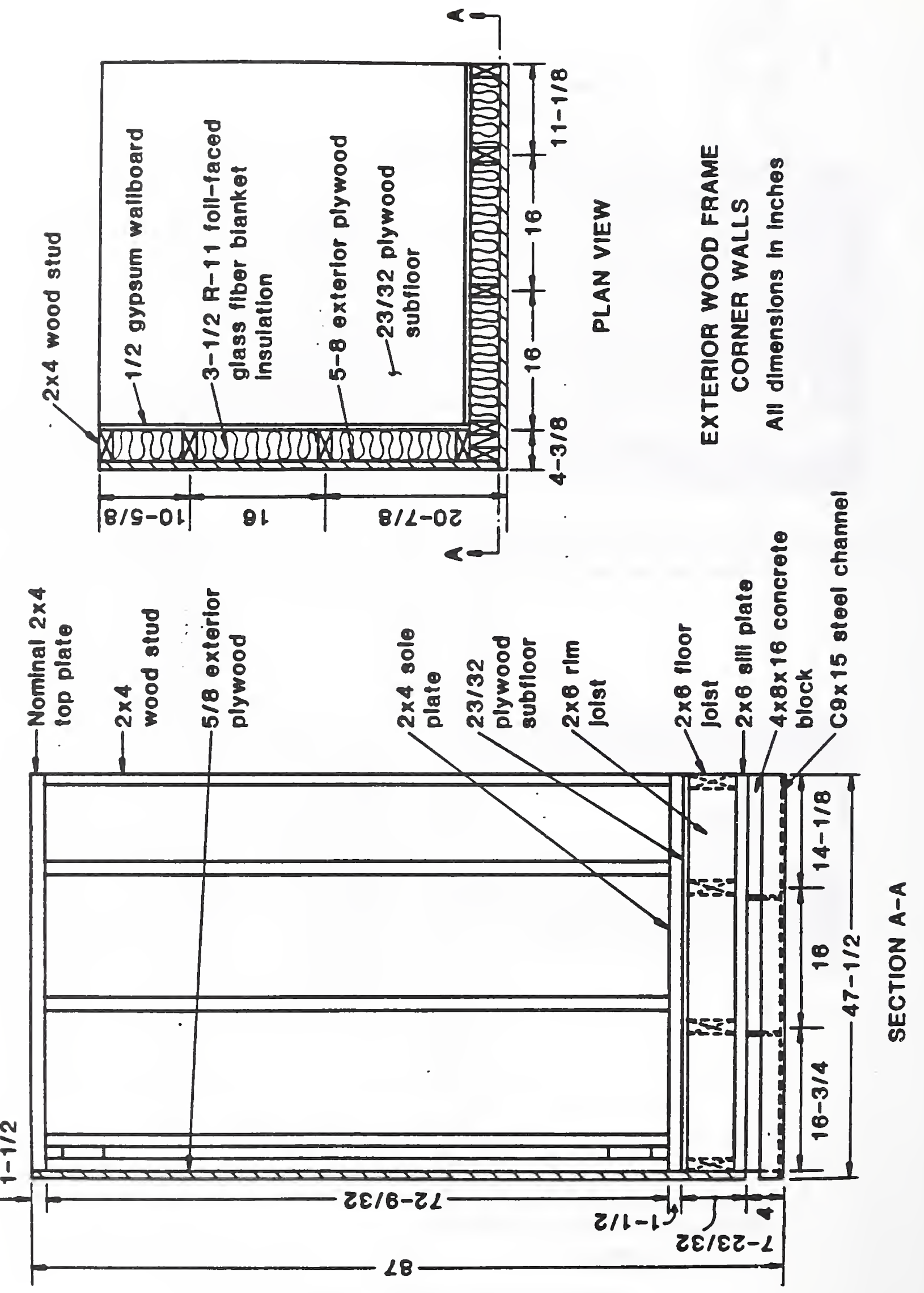


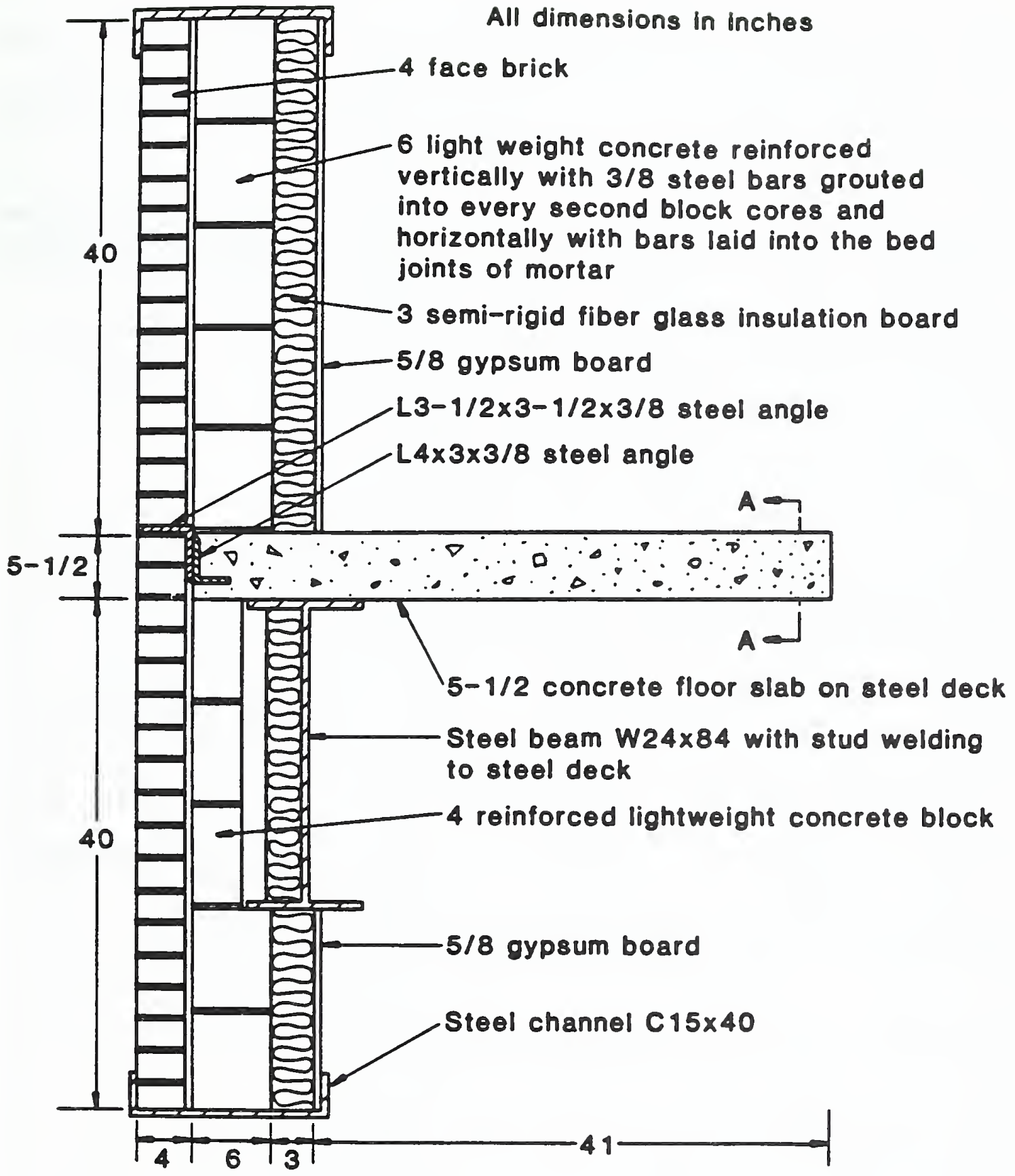

MASONRY WALL WITH CONCRETE FLOOR

Figure 8.a Masonry Wall and Concrete Floor Constructions 


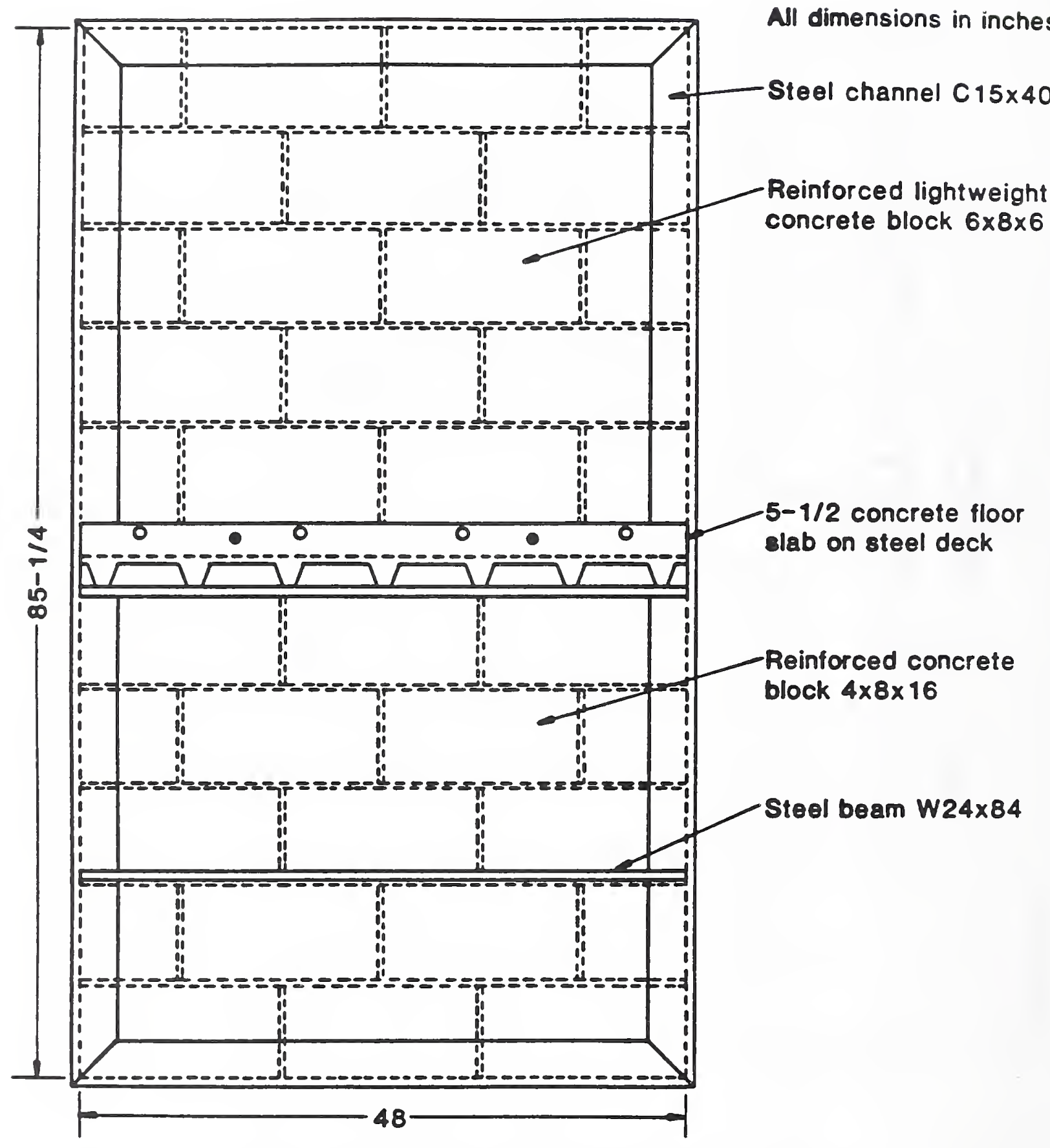

INTERIOR VIEW OF EXTERIOR WALL-FLOOR CONSTRUCTION

Figure 8.b Front Vlew of Masonry Wall and Concrete Floor Constructions 

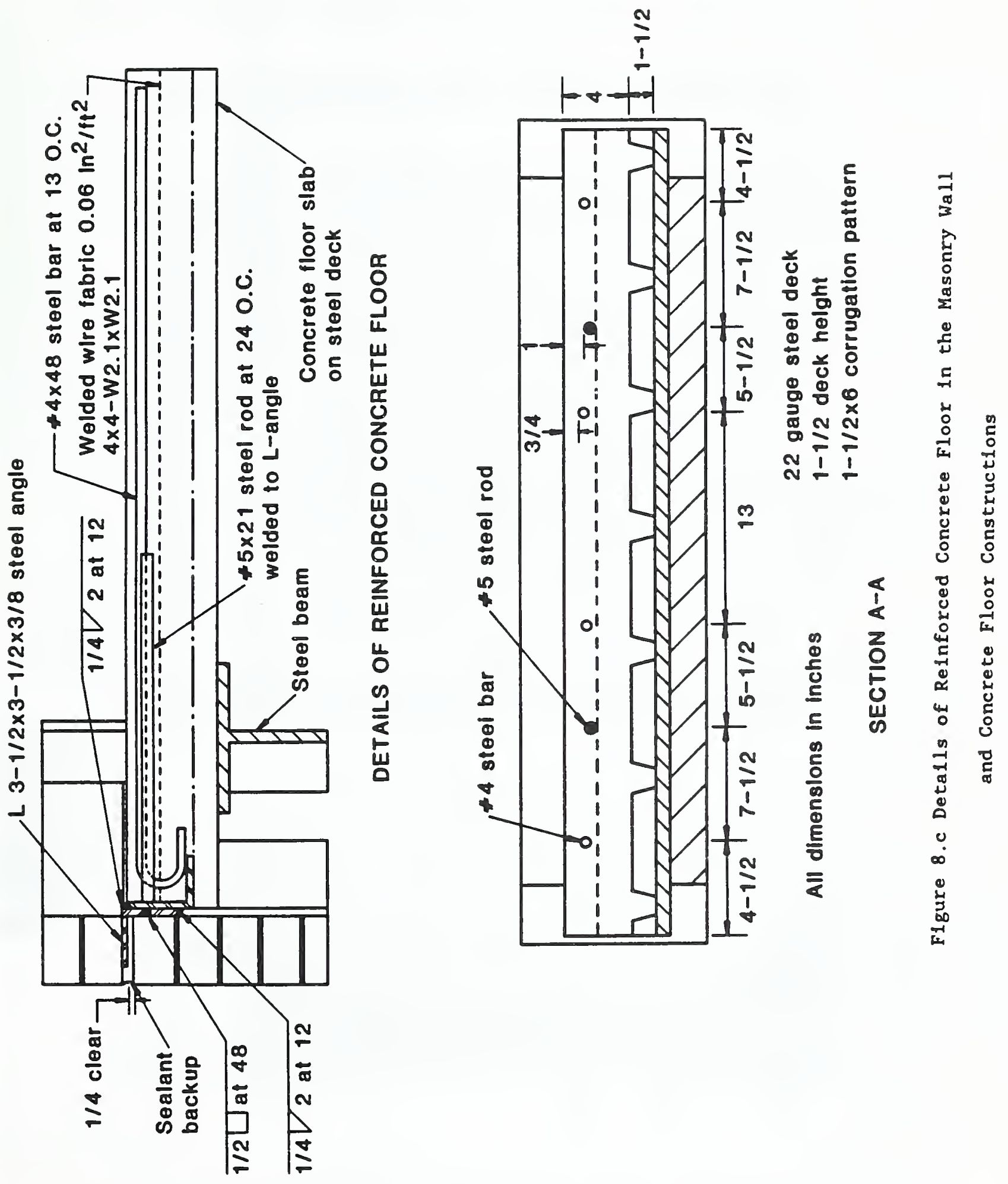


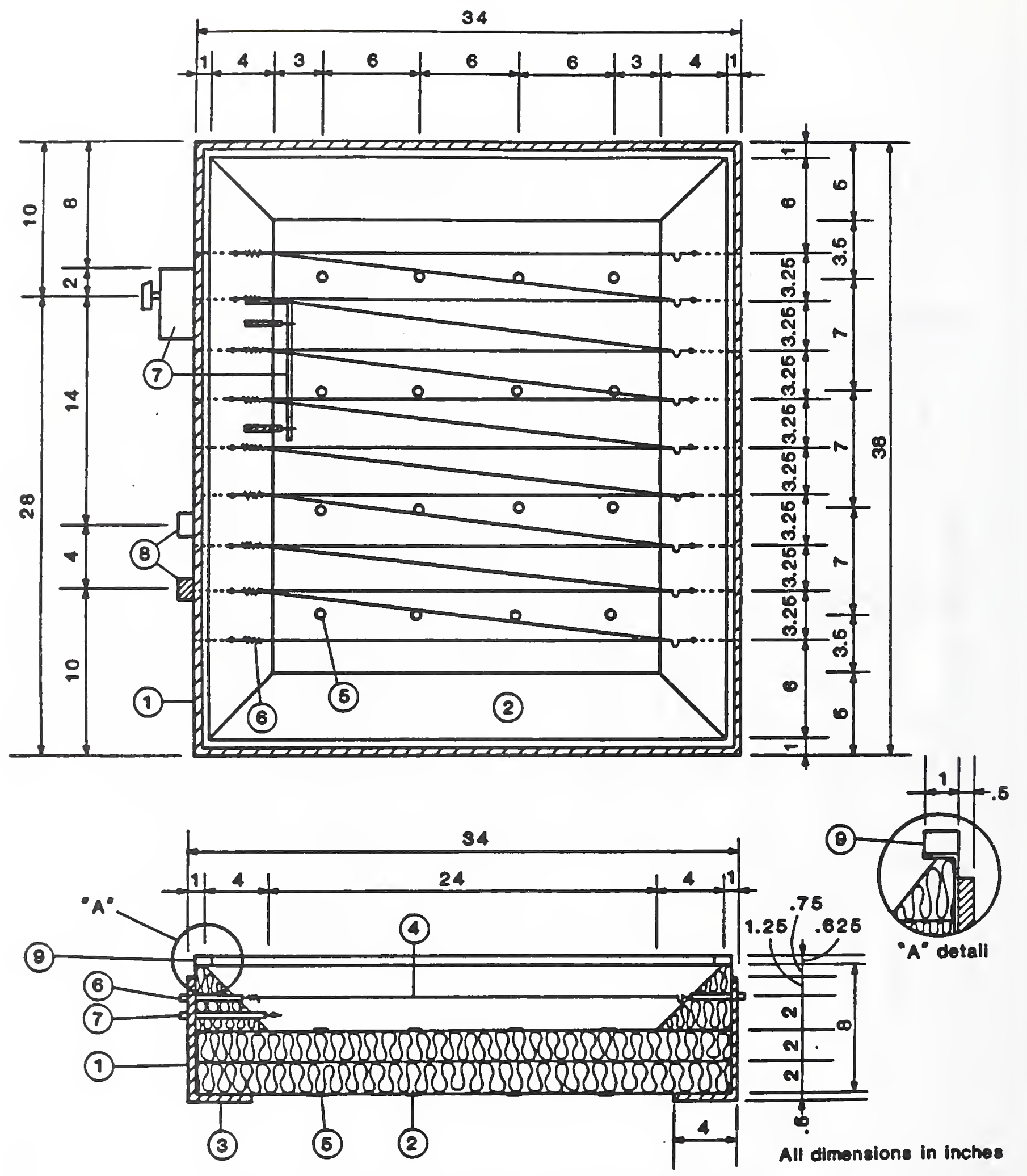

Figure 9. Construction Details of Portable Calorimeter for Flat Surface 
Parts of Portable Calorimeter for Flat Surface (Refer to Figure 9)

1. Frame -

$1 / 2$ inch fir plywood, glued to insulation board and nailed at corners.

2. Insulation - Rigid glass-fiber, $4 \mathrm{ft} . \mathrm{x} 2 \mathrm{ft}, \mathrm{x} 2 \mathrm{in.}$ thick, foil-faced insulation. Cut boards to suit, stagger joints with foiled side exposed, and bond boards with contact adhesive. Fill joints with crumbled glass fiber insulation and seal with aluminum foil duct tape.

3. Plywood - Cover edges of back box wall with 4 in. wide $x 1 / 4$ in. thick plywood, and fill the joints between insulation boards with small pieces of glass-fiber board and adhesive.

4. Electric Heating

Element - Bare nickel chromium wire with B\&S gauge No. 28 wire diameter.

5. Thermopile - 16-junction pair thermopile of copper-constantan thermocouples ( $B \& S$ guage No. 26, 0.015 inch wire diameter, single wire, nylon insulated) with junctions positioned on both interior and exterior surfaces of the back box wall.

6. Ceramic Stand-off

Insulator with

Steel Hook or

Spring

Insulator support (cylinder-shaped, 3 inches in length with $8 / 32$ in. threaded holes at both ends) attached to plywood frame.

7. Safety

Thermostat - Remote bulb controller with a sensing element measuring $1 / 2$ in. diameter $\times 3-9 / 16$ in. long.

8. Caps for Electric

Cable

Connections - Power input for the electric heater and the voltage signals from the thermopile.

9. Rubber Foam - 5/8 in thick strip glued over a 1/32 in. thick aluminum angle frame installed along the edges of the calorimeter box. 


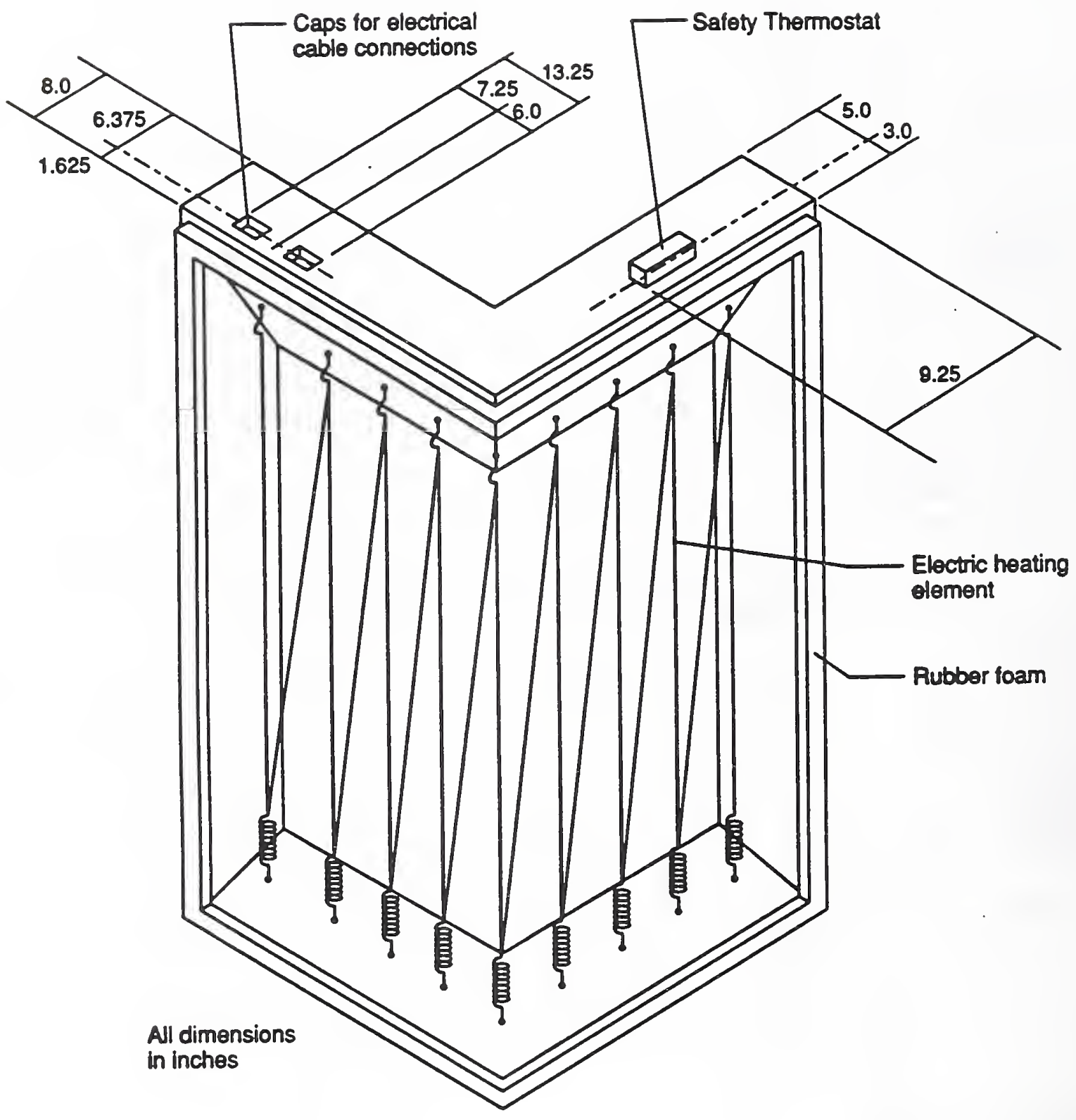

Figure 10.a Construction Details of Portable Calorimeter for Surfaces of a Bullding Corner 


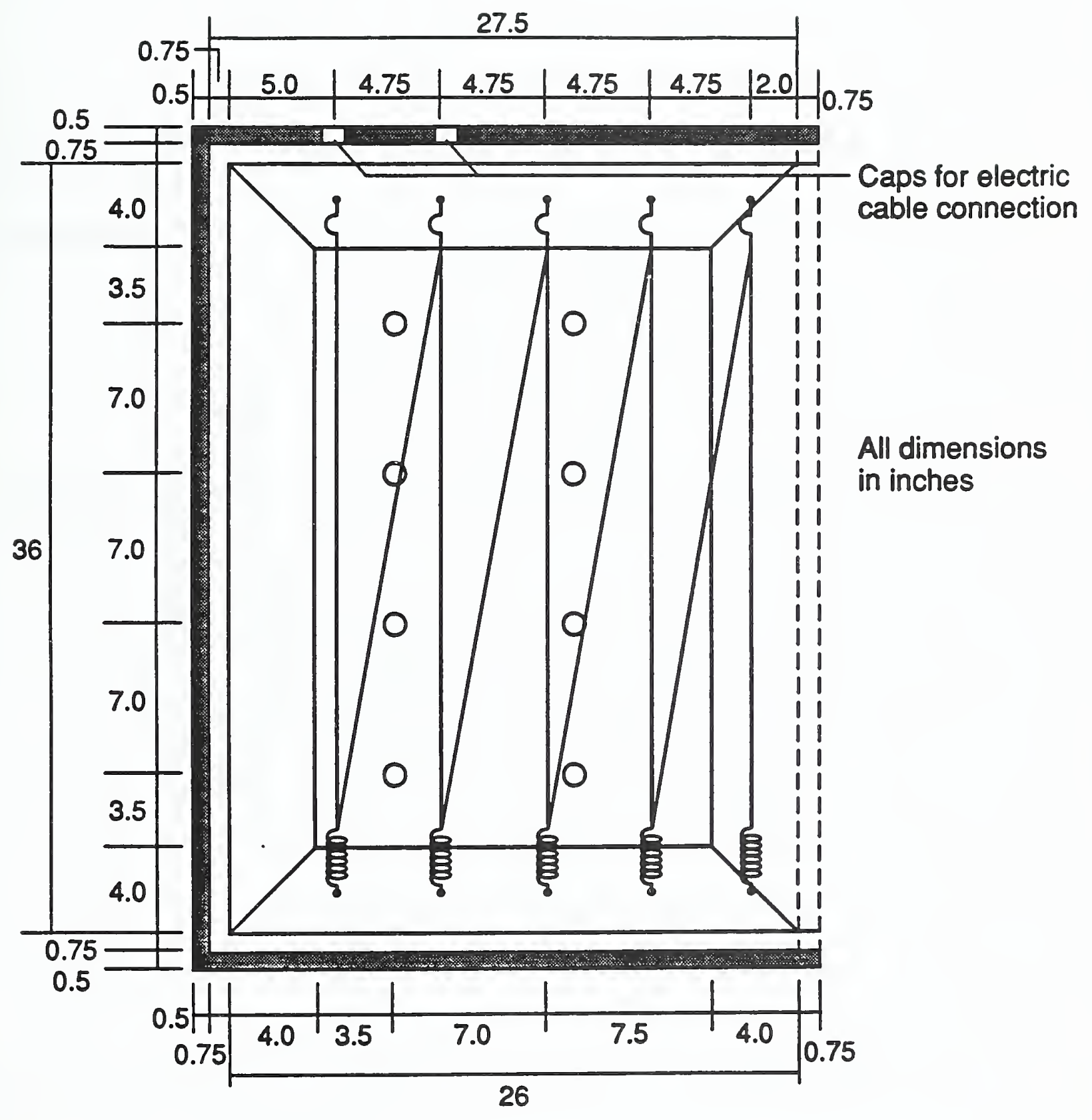

Figure 10.b Front View of the Corner Calorimeter 


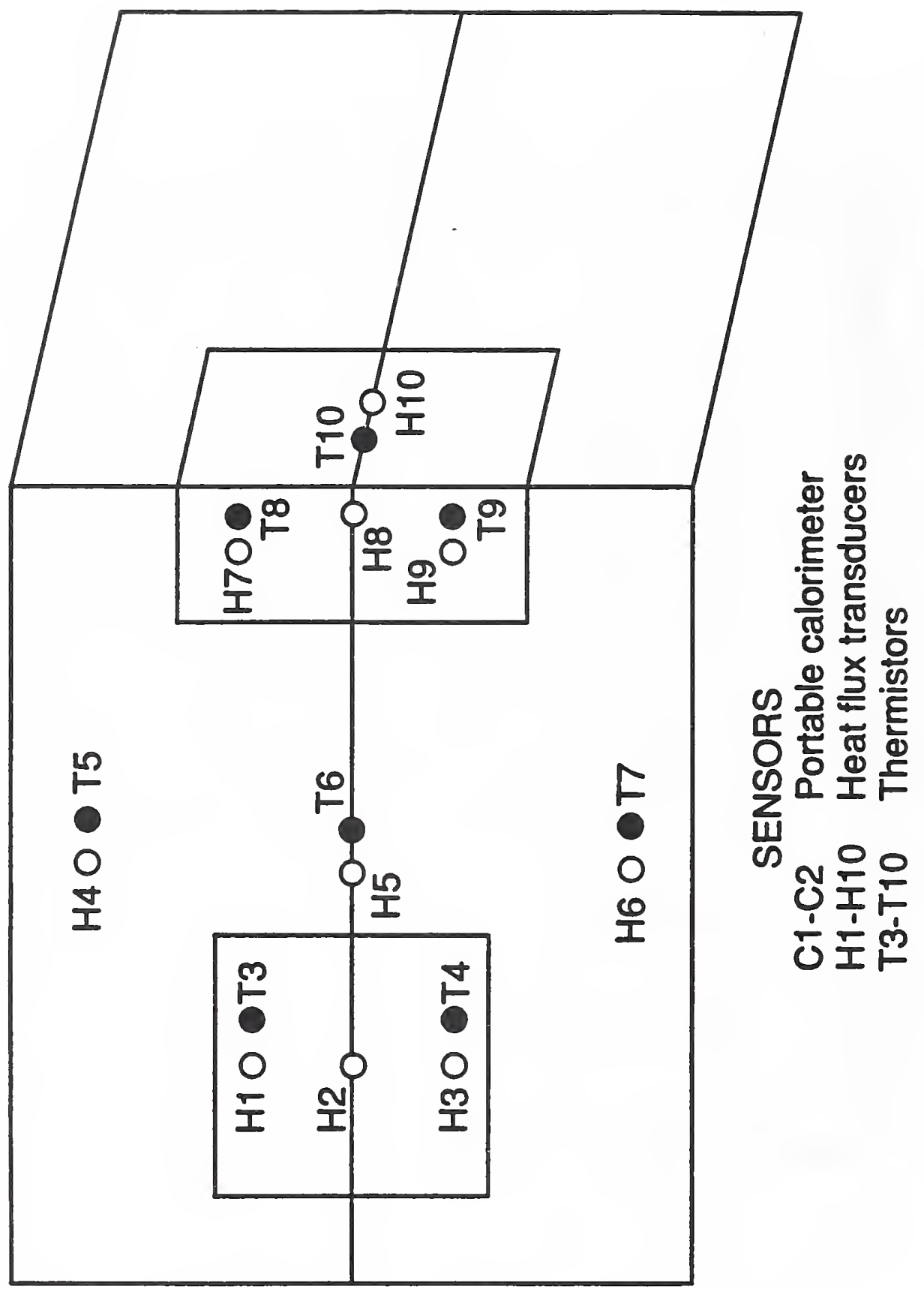

들 


\begin{tabular}{|c|c|c|}
\hline \multirow[t]{3}{*}{$\begin{array}{l}\text { NIST-114A } \\
\text { (REV. 3-89) }\end{array}$} & \multirow{3}{*}{$\begin{array}{l}\text { U.S. DEPARTMENT OF COMMERCE } \\
\text { NATIONAL INSTITUTE OF STANDARDS AND TECHNOLOGY }\end{array}$} & $\begin{array}{l}\text { 1. PUBLCATION OR REPORT NUMBER } \\
\text { NISTIR } 90-4258\end{array}$ \\
\hline & & 2. PERFORMING ORGANIZATION REPORT NUMBER \\
\hline & & $\begin{array}{r}\text { 3. PUBUCATION DATE } \\
\text { MARCH } 1990\end{array}$ \\
\hline
\end{tabular}

The Evaluation of Thermal Bridges Using a Mobile Test Facility

5. AUTHOR(S)

Jin B. Fang, Richard A. Grot

6. PERFoRAING ORGANIZATION (IF JOINT OR OTHER THAN NIST, SEE INSTRUCTIONS)

U.S. DEPARTMENT OF COMMERCE

NATIONAL INSTITUTE OF STANDARDS AND TECHNOLOGY

GAITHERSBURG, MD 20899

7. CONTRACT/GRANT NUMBER

8. TYPE OF REPORT AND PERIOD COVERED

9. SPONSORING ORGANIZATION NAME AND COMPLETE ADDRESS (STREET, CITY, STATE, ZIP)

Office of Building Energy Research and Development, U. S. Department of Energy

U. S. Department of Commerce

10. SUPPLEMENTARY NOTES

DOCUMENT DESCRIBES A COMPUTER PROGRAM; SF-185, FIPS SOFTWARE SUMMARY, IS ATTACMED.

11. ABSTRACT (A 200-WORD OR LESS FACTUAL SUMMARY OF MOST SIGNIFICANT INFORMATION. JF DOCUMENT INCLUDES A SIGNIFICANT BIBLOGRAPHY OR UTERATURE SURVEY, MENTION IT HERE.)

The construction details of a mobile test facility with removable walls and roof used for installation and performance evaluation of the test specimens are described. Descriptions of the overall performance of a newly developed portable calorimeter employed for quantification of the heat flow through exterior walls of a building corner are given. Laboratory tests were conducted using an in-situ thermal resistance measurement technique to evaluate the performance of thermal bridges occuring in a metal-frame, insulated wall construction. The local heat flow rates and thermal resistances under steady-state conditions were measured by means of portable calorimeters, heat flux transducers and thermistors at various locations of the test structure. The measured wall thermal resistance values were compared with the predicted values obtained by the zone and the series/parallel resistance methods. The calorimeter neasurement generally gave lower thermal resistanee values than the heat flux transducers due to enhanced heat conduction through highly conductive fasteners and framing members.

12. KEY WORDS (6 TO 12 ENTRIES; ALPHABETICAL ORDER; CAPITALIZE ONLY PROPER NAMES; AND SEPARATE KEY WORDS BY SEMICOLONS)

Building, exterior envelope, heat flux, in-situ, measurements, portable calorimeter, temperature, thermal bridge, thermal resistance, wall.

FOR OFFICIAL DISTRIBUTION. DO NOT RELEASE TO NATIONAL TECHNICAL INFORMATION SERVICE (NTIS).

ORDER FROM SUPERINTENDENT OF DOCUMENTS, U.S. GOVERNMENT PRINTING OFFICE, WASHINGTON, DC 20402.

ORDER FROM NATIONAL TECHNICAL INF ORMATION SERVICE (NTIS), SPRINGFIELD, VA 22161.

\begin{tabular}{|l|} 
14. NUMBEA OF PRINTED PAGES \\
34 \\
\hline 15. PRICE $\mathrm{A} 03$ \\
\hline
\end{tabular}




